\title{
RELASI ALKHAIRAAT-NU DI MANADO TAHUN 1955-1998 (Studi Pertemuan Antara Alkhairaat dan NU dalam Konteksd Ideologi Sosio-kultiral)
}

\author{
Lisa Aisyah Rasyid \\ Pascasarjana UIN Sunan Kalijaga Jogjakarta \\ Lisa.aisyah@iain-manado.ac.id
}

\begin{abstract}
Alkhairaat and NU are two different organizations and structures. NU is active in various fields with not small political dimensions, while Alkhairaat focuses on education and da'wah. But in Manado it is interesting, the Islamic community considers that Alkhairaat is an embryo of NU. This is certainly related to the historical-sociological factors of these two institutions born in the local context. This study wants to answer two questions; First, what is the background of the relationship between Alkhairaat and NU in Manado in 1955-1998 and what is the dynamics and pattern characteristics of the Alkhairaat relationship with NU in Manado during 1955-1998. Temporally, this research was restricted from 1955 because this year Alkhairaat built its social relations with NU, which at that time was the party participating in the first election in Indonesia. The final limitation of the study was set in 1998 because this year there was a change in the body of $N U$ by declaring the PKB as a party formed by and for NU citizens, but open to anyone including non-Muslims. This caused conflict in the Alkhairaat-NU relationship in Manado,
\end{abstract}

Keywords: NU, Alkhairaat, Manado, Education, Da'wah, Historical-Sociological

Abstrak. Alkhairaat dan NU adalah dua organisasi yang berbeda secara kelembagaan maupun struktur. NU aktif dalam berbagai bidang dengan dimensi politiknya yang tidak kecil, sedangkan Alkhairaat fokus pada pendidikan dan dakwah. Namun di Manado menarik, masyarakat Islam menganggap bahwa Alkhairaat adalah embrio dari NU. Ini tentu terkait dengan faktor historis-sosiologis kedua lembaga ini lahir dalam konteks lokal. Penelitian ini ingin menjawab dua pertanyaan; Pertama, Bagaimana latarbelakang terjalinnya hubungan antara Alkhairaat dan NU di Manado pada tahun 1955-1998 dan Bagaimana dinamika dan karakteristik pola relasi Alkhairaat dengan NU di Manado selama tahun 1955-1998. Secara temporal, penelitian ini dibatasi dari tahun 1955 karena pada tahun inilah Alkhairaat membangun relasi sosialnya dengan $N U$ yang saat itu menjadi partai peserta dalam Pemilu pertama di Indonesia. Adapun batasan akhir penelitian ditetapkan tahun 1998 karena pada tahun ini terjadi perubahan di tubuh $N U$ dengan mendeklarasikan PKB sebagai partai yang dibentuk oleh dan untuk warga NU, namun terbuka bagi siapapun termasuk non-Muslim. Hal ini menimbulkan konflik dalam relasi Alkhairaat-NU di Manado.

Kata Kunci: NU, Alkhairaat, Manado, Pendidikan, Dakwah, Historis-Sosiologis

\section{Pendahuluan}

Berbicara tentang Alkhairaat, tidak akan terlepas dari nama besar al'Allamah al-Habib Sayyid Idrus bin Salim Aljufri (selanjutnya dikenal dengan sebutan Guru Tua). Alkhairaat adalah lembaga pendidikan Islam yang didirikan oleh Guru Tua, seorang ulama asal Hadramaut (Yaman Selatan) pada tahun 1930 di Palu Sulawesi Tengah. 
Lembaga pendidikan Alkhairaat yang beliau dirikan menjadi tonggak pendidikan Islam di Sulawesi Tengah. ${ }^{1}$ Selanjutnya dalam waktu yang relatif singkat, cabang-cabangnya telah berkembang di wilayah Kawasan Timur Indonesia (selanjutnya di singkat KTI) termasuk wilayah Kota Manado.

Alkhairaat menjadi simbol perjuangan Guru Tua untuk mencetak generasi yang berkualitas. Alkhairaat juga menjadi simbol perjuangan melawan kolonialisme dan missionaris kristen di Manado dengan menggunakan strategi pendidikan sebagai basisnya.

Alkhairaat memiliki tancapan sejarah yang kuat di Sulut tak terkecuali kota Manado. Lembaga ini memiliki ikatan emosional yang kuat dengan masyarakat Muslim di kota tersebut. Demikian kuatnya ikatan emosional tersebut, mayoritas masyarakat Muslim Manado mempunyai rasa memiliki yang tinggi terhadap Alkhairaat. Lembaga ini telah menjadi bagian dari keseharian di mana mereka tumbuh dan berkembang sebagai sebuah masyarakat.

Kuatnya ikatan emosional Alkhairaat dan masyarakat Muslim Manado merupakan potensi tersendiri bagi lembaga tersebut. Tidak banyak lembaga yang mampu menciptakan hubungan yang demikian kuat dengan partisipannya, sebagaimana Alkhairaat.

Merupakan sebuah fakta bahwa sejarah Alkhairaat di Manado memiliki dinamika yang luas, baik dalam konteks sosial, politik maupun agama. Alkhairaat sebagai sebuah lembaga pendidikan Islam, memiliki peran dan jasa yang sangat besar. Terutama terhadap masyarakat Muslim di Sulawesi Utara (Sulut) termasuk Manado. Alkhairaat besar jasanya dalam mendidik dan

\footnotetext{
${ }^{1}$ M. Noor Sulaiman P.L., Al-Khairaat dan Perubahan Sosial Masyarakat Sulawesi Tengah (Palu: L3M STAIN Dato Karama, 2000), hlm. 3
}

menciptakan kader muslim. Lembaga pendidikan Alkhairaat telah mencetak banyak kader berkualitas. Mereka tidak saja dapat berkiprah pada level daerah, namun juga nasional. Kader-kader Alkhairaat bertebaran di berbagai bidang kehidupan.

Kehadiran Alkhairaat sebagai institusi pendidikan Islam di Manado dengan segala aktivitas sosial keagamaannya yang berafiliasi kepada mazhab Ahlussunnah wal Jama'ah dengan NU sebagai mitranya, namun bersikap moderat dan progresif dalam merespon problematika sosial politik keagamaan dan kebangsaan, ${ }^{2}$ telah mampu memberi corak sendiri dalam keislaman masyarakat Muslim di Manado. Institusi ini secara kelembagaan, tersebar di hampir seluruh wilayah Manado. Realitas ini menjadikan mayoritas Muslim di Manado menjadi bagian dari abna'ul khairaat, yakni keluarga besar Alkhairaat.

$\mathrm{NU}^{3}$ sendiri, kemunculannya sebagai sebuah organisasi sosial keagamaan, sebagaimana halnya Alkhairaat tidak bisa dilepaskan dari realitas yang mempengaruhinya ketika itu, yaitu dua realitas yang berupa realitas ke-Indonesiaan dan ke-Islaman. Kedua realitas tersebut sama-sama mempunyai keterkaitan yang sangat erat dengan kondisi dunia global, yakni realitas dunia yang masih diwarnai dengan praktik kolonialisme dan imperialisme dunia Barat atas dunia Timur, yang bukan saja sebagai bentuk

${ }^{2}$ Gani Jumat, Nasionalisme Ulama: Pemikiran Politik Kebangsaan Sayyid Idrus Bin Salim Aljufry, 1891-1969 (Jakarta: Kementrian Agama RI, 2012), hlm. 105-106

${ }^{3}$ Nahdlatul Ulama (NU) berasal dari kosakata Arab Nahdlah yang berarti bangkit dan Ulama yang merupakan bentuk jama' dari kata 'alim, yaitu orang yang menguasai ilmu agama secara mendalam. Jadi secara hariah Nahdlatul Ulama berarti kebangkitan para Ulama (Kiai). 
penghisapan secara ekonomi dan pemaksaan kehendak dan penindasan secara politik suatu bangsa atas bangsa yang lain.

Sementara dalam konteks kebangsaan, hal tersebut merupakan realitas historis bangsa indonesia pada akhir abad ke-19 dan awal abad ke- 20, yakni masa kolonial. Pada masa ini, di antaranya muncul perlawanan kepada pemerintah kolonial secara fisik. ${ }^{4}$ Selain itu, muncul pula gerakan kebangkitan kembali agamayg menampakkan diri dalam bentuk sekolah-sekolah dan perkumpulan tarekat di banyak tempat di jawa maupun di luar jawa.

Organisasi keagamaan bentukan K.H. Hasyim Asy`ari ini cenderung untuk melindungi pembelaan terhadap apa yang disebut dengan tradisi bawah (low tradition) dari penggusuran kelompok pembaharu yang dipelopori oleh K.H. Ahmad Dahlan dengan organisasi muhammadiyah bentukannya, yang mewakili kelompok tradisi tinggi.

Realitas NU yang memang mempunyai ciri melekat yang demikian, menjadi sangat wajar jika pengikutnya mayoritas berasal dari kalangan pedesaan yang mempunyai tradisi agraris cukup kuat. Pada masyarakat yang demikian, tradisi dan budaya paternalistiknya masih sangat kuat, maka tidak terlalu mengherankan kalau sampai dengan saat ini warga NU masih memberikan penghormatan yang cukup tinggi kepada ulama atau Kiainya, sebagai sang "patron".

Kondisi kultur masyarakat NU yang berakar pada budaya agraris cukup kuat ini masih ditambah dengan

${ }^{4}$ Perlawanan dimaksud yang perlu menjadi catatan adalah perlawanan besar di antaranya: Perang Diponegoro (1825-1830), Perang Padri (1821-1938), Perang Aceh (18731912) serta pemberontakan Petani Banten 1888. Sartono Kartodirjo, Pemberontakan Petani Banten 1888 (Jakarta: Pustaka Jaya, 1984), hlm. 13-14. model dan pola pendidikan yang dikembangkan oleh organisasiini, yaitu pola pendidikan pesantren. Sementatara dalam ajarannya NU menempatkan fikih (hukum Islam) sebagai sentral dalam kehidupan bermasyarakat. Segala perilaku sehari-hari selalu dilihat berdasarkan kacamata fikih, dapat dikatakan masyarakat NU adalah masyarakat fikih.

NU selalu berpedoman pada kaidah fikih yang menyatakan: "alMukhtafadlatu 'ala qadimi al-Shalih wa al-Akhdlu bi al-Jadidi al-Ashlakh (memelihara tradisi lama yang bagus dan mengambil tradisi baru yang lebih bangsa). Sebagai dasar keberagamaan NU sebagaimana yang terncantum dalam Anggaran Dasarnya yaitu: alQur'an, Sunnah, Ijma', dan Qiyas. Menempatkan 4 imam mazhab, yaitu: Imam Malik, Imam Hanafi, Imam Syafi'i dan Imam Hambali sebagai rujukan fikihnya. Sementara dalam bidang teologisnya berpegang pada pemikirannya Imam al-Asy'ari dan Imam al-Maturidi, dan dalam bertasawuf berpegang pada imam alGhazali dan Imam Junaed al-Baghdadi. Kesemuanya itu disebut oleh Nahdliyin sebagai "Aswaja" (Ahlussunnah wal Jama'ah), sebagai pemahaman atas dasar tersebut.

Islam memperoleh tempatnya di Manado, sebagian besar melalui Alkhairaat (abna'ul al-khairaat). Hal ini dikarenakan dalam pandangan masyarakat Muslim Manado, Alkhairaat adalah bagian dari NU. Padahal tidak demikian halnya. NU dan Alkhairaat hanyalah sebagai mitra dalam mengawal dan melestarikan nilai-nilai dan tradisi Ahlussunnah wal Jama'ah (selanjutnya disbut Sunni). Alkhairaat maupun NU, keduanya adalah dua hal yang berbeda baik secara kelembagaan maupun secara organisatoris. Masingmasing memiliki struktur kepengurusan yang berbeda. Secara organisatoris, 
kepengurusan Alkhairaat berpusat di Palu Sulawesi Tengah sedangkan NU berpusat di Jombang Jawa Timur.

Alkhairaat di Manado adalah murni sebagai institusi pendidikan Islam yang aktif dalam kegiatan sosialkeagamaan saja dengan didukung oleh berbagai unit organisasinya di antaranya: Himpunan Pemuda Alkhairaat (HPA), Wanita Islam Alkhairaat (WIA), dan Media Massa Alkhairaat. Karena memang pada awalnya kehadiran Alkhairaat di Manado adalah untuk mengimbangi arus missionaris kristen.

Berbeda dengan NU yang awalnya adalah sebuah jam'iyah diniyah atau organisasi sosial keagamaan ${ }^{5}$ di mana kehadirannya adalah untuk melindungi praktik dan pemikiran keagamaan Muslim Indonesia yang beda dengan praktik dan pemikiran keagamaan Muslim Timur Tengah, khususnya Arab Saudi yang puritanistik $^{6}$ dikhawatirkan akan mengancam kelestarian paham Ahlussunnah wal Jama'ah.7 Selanjutnya, pada tahun 1955 dalam dinamikanya muncul sebagai partai politik, lalu kemudian fakum dan kembali eksis (khususnya di Manado) pada tahun 1987 - atas bantuan Alkhairaat dengan terpilihnya K.H. Hasyim Arsyad (pengurus Alkhairaat yang juga merupakan murid langsung dari Guru Tua, Sayyid Idrus bin Salim Al-Jufri) sebagai Ketua Rais NU di wilayah Manado cabang Sulawesi Utara.

${ }^{5}$ Lih. A. Gaffar Karim, Metamorfosis $N U$ dan Politisasi Islam Indonesia (Yogyakarta: Pustaka Pelajar \& LKiS Yogyakarta, 1995), hlm. 7

${ }^{6}$ Khamami Zada \& A. Fawaid Sjadzili (ed.), Nahdlatul Ulama: Dinamika Ideologi dan Politik Kenegaraan (Jakarta: Kompas, 2010), hlm. 4

${ }^{7}$ Khoirul Fathoni \& Muhammad Zen, $N U$ Pasca Khittah (Prospek Ukhuwah dengan Muhammadiyah (Yogyakarta: Media Widya Mandala, 1992), hlm. 10
Tahun 1998 tepat setelah tumbangnya rezim orde baru, NU kembali terjun dalam politik praktice pemerintahan dengan melahirkan PKB. Dinamika politik yang sering terjadi di tubuh NU ini, secara tidak langsung menurut Asep Saiful Muhtadi,8 akan menimbulkan pergeseran sosiologis kaum nahdliyin. NU yang sebelumnya cenderung diurus oleh kalangan tradisional yang lebih mendasarkan pada pola-pola hubungan emosional, ke depan ia akan menjadi organisasi modern yang dikelola oleh kalangan profesional yang lebih mendasarkan pada pola-pola hubungan rasional. Hal ini jelas akan sangat bertentangan dengan realita kehidupan sosial abnaul khairaat secara keseluruhan pada umumnya baik di pusat maupun daerah, khusus di Manado yang sangat mengutamakan hubungan emosional ketimbang rasional.

Beranjak dari kemungkinan tersebut di atas, seiring dengan intensnya hubungan antara Alkhairaat dengan NU, menjadikan Alkhairaat turut serta baik dalam kepengurusan maupun aktivitas organisasi NU namun masih tetap konsisten pada posisi awalnya sebagai sebuah institusi sekaligus organisasi Islam yang fokus pada kegiatan sosial-keagamaan dan tidak turut serta dalam politik praktice sebagaimana NU.

Sebuah fakta yang tidak bisa dipungkiri bahwa meskipun NU adalah sebuah organisasi sosial keagamaan, namun dimensi politik dalam aktifitas NU tidak kecil, terutama dalam tujuan pendiriannya yang sejak awal telah terkandung muatan politik, yaitu

${ }^{8}$ Asep Saeful Muhtadi, Komunikasi Politik Nahdlatul Ulama: Pergulatan Pemikiran Politik Radikal dan Akomodatif (Jakarta: LP3ES, 2004), 72-73 
penggalangan nasionalisme di tengah iklim kolonial saat itu. ${ }^{9}$

Secara temporal, penelitian ini dibatasi dari tahun 1955 sampai dengan tahun 1998. Dipilihnya tahun 1955, karena pada tahun tersebut untuk pertama kalinya NU hadir di Manado, namun dalam bentuk parpol yang sekaligus juga sebagai awal pertemuan Alkhairaat dan NU di Manado. Sedangkan pembatasan sampai pada tahun 1998 karena pada tahun ini, perubahan yang mengejutkan kembali terjadi di tubuh $\mathrm{NU}$ dengan secara terang-terangan membuat parpol sendiri yang diberi nama PKB (Partai Kebangkitan Bangsa).

Berdasarkan eksplanasi historis tersebut di atas, maka yang menjadi fokus permasalahan dalam penelitian ini yakni tentang Relasi Alkhairaat-NU di Manado Tahun 1955-1998 (Studi Historis-Sosiologis). Berdasarkan fokus masalah tersebut, maka penulis kemudian merumuskan beberapa permasalahan yang nantinya akan menjadi pokok pembahasan dalam tesis ini: Bagaimana latarbelakang terciptanya titik temu antara Alkhairaat dan NU dalam interaksi sosial, politik, dan keagamaan keduanya di Manado, Dinamika hubungan keduanya dalam interaksi tersebut dalam kurun waktu antara tahun 1955-1998.

\section{Pembahasan}

\section{Terbentuknya Relasi Alkhairaat-NU di Manado}

Charles H. Cooley membagi masyarakat dalam dua golongan kelompok, yaitu kelompok primer dan kelompok sekunder.Unsur esensial dalam kelompok primer adalah adanya relasi sosial. ${ }^{10}$ Relasi sosial merupakan

\footnotetext{
${ }^{9} \mathrm{~A}$. Gaffar Karim, Metamorfosis $\mathrm{NU}$ dan Politisasi Islam di Indonesia, hlm. 12

${ }^{10}$ Kompasiana, "Struktur Sosial dan Interaksi Sosial”, dalam
}

hubungan sosial yang dinamis antar orang perorangan maupun antar kelompok.Terbentuknya relasi sosial adalah sebagai pengaruh timbal balik di antara mereka dalam usaha memecahkan persoalan yang diharapkan dan dalam usaha untuk mencapai tujuannya.Faktor pendorong relasi sosial adalah adanya kontak sosial melalui komunikasi secara langsung atau melalui media.

Berbicara mengenai relasi Alkhairaat dan NU di Manado pada tahun 1955-1998, adalah sama halnya membicarakan duahal yang berbeda. Alkhairaat dan NU adalah organisasi Islam beraliranAhlussunnah wal Jama'ah.Bedanya, Alkhairaat bersifat non-politik dan bergerak di bidang pendidikan dan dakwah,sementara NU meski bergerak di bidang sosial dan keagamaan, namun memiliki orientasi politik yang tidak sedikit.

Oleh karena itu penulis berpendapat, terbentuknya relasi antara Alkhairaat dan NU saat itu, tidak terlepas dari adanya mayoritas basis massa dan ideologi yang sama. Baik Alkhairaat maupun NU memiliki basis massa pondok pesantren yang beraliran Ahlussunnah wal Jama'ah. Jadi, bisa dikatakan relasi yang terbentuk antara Alkhairaat dan NU adalah relasi kultural bukan struktural, karena didasari oleh latar ideologi yang sama dan sudah tertanam sejak awal. Hal ini tentunya dapat dengan mudah menyatukan visi dan misi ke depan dalam membangun relasi sosial (pendidikan, politik, dan sosial-keagamaan) yang tentunya bisa saling menguntungkan.

\section{Pertemuan Alkhairaat dan NU}

Terbentuknya relasi Alkhairaat dan NU tidak terlepas dari sejarah awal mula pertemuan pendiri kedua organisasi ini.Sebelum Guru Tua hijrah

http://www.kompasiana.com/, aksesstangal 26 Mei 2016. 
ke Palu Sulawesi Tengah dan mendirikan Alkhairaat pada tahun 1930, empat tahun sebelumnya yaitu tahun 1926, Guru Tua sempat tinggal selama dua tahun di Jombang Jawa Timur.Sebuah pusat Islam tradisional tempat dia bertemu dengan dengan Hadratus Syaikh KH.Hasyim Asy'ari pendiri Nahdlatul Ulama (NU), yang berdiri pada tahun 1926 .

Namun menurut Azyumardi Azra, sulit mengetahui pengaruh pertemuan dengan Hasyim Asy'ari terhadap pemikiraan Sayyid Idrus.Barangkali terlalu simplistik untuk menyimpulkan bahwa pertemuan Sayyid Idrus dengan K.H. Hasyim Asy'ari menghasilkan "tradisionalisme" Alkhairaat. 11

Gani Jumat menegaskan, bahwa pertemuan Guru Tua dengan K.H. Hasyim Asy'ari, tidak membawa pengaruh yang kemudian membentuk corak pemikiraan Alkhairaat.Jauh sebelum bertemu Asy'ari, Guru Tua telah memiliki bekal ilmu agama yang cukup memadai dari ayahnya Habib Salim maupun kakeknya Habib 'Alawi dan beberapa Ulama besar di Hadramaut. Selain itu ketika masih di Hadramaut di samping berprofesi sebagai guru, Guru Tua juga menjabat sebagai mufti Taris Hadramaut, bahkan sampai dibuang oleh Kolonial inggris ke Indonesia pun, jabatan mufti itu masih diembannya. ${ }^{12}$

Menurut hemat penulis, boleh jadi mereka seringkali bertemu selama di Jombang, berdiskusi (sharing) menyangkut nasib umat Islam yang sedang terpuruk akibat dijajah oleh kolonialis.Sehingga

semakin

${ }^{11}$ Azyumardi Azra, Jaringan Global dan Lokal Islam Nusantara (Bandung: Mizan, 2002), hlm. 170-171.

${ }^{12}$ Gani Jumat, Nasionalisme Ulama: Pemikiran Politik Kebangsaan Sayyid Idrus Bin Salim Aljufry, 1891-1969 (Jakarta: Kementrian Agama RI, 2012), hlm. 69. memperkuat komitmen Guru Tua untuk membuka sebuah pendidikan Islam karena ada kesamaan misi perjuangan, corak ideologis dan mazhab yang dianut, yaitu Ahlussunnah wal Jama'ah.

Dengan demikian, secara historis, baik Alkhairaat maupun NU sama-sama didirikan oleh Ulama Sunnisme. Alkhairaat didirikan oleh Sayyid Idrus bin Salim Aljufriy dan NU didirikan oleh K.H. Hasyim Asy'ari. Ideologi kedua ulama ini, berafiliasi pada paham Ahlussunnah wal Jama'ahdan senantiasa mempertahankan tradisi-tradisi Sunni dan tradisi lokalyang dianggap baik dengan memasukkan unsur-unsur Islam ke dalam-nya.

Tidak bisa dipungkiri antara NU dan Alkhairaat, memiliki titik temu dalam konteks ideologi dan kultur budaya yang telah dibangun oleh kedua organisasi ini. Sebagai dasar keberagamaan NU, sebagaimana yang tercantum dalam Anggaran Dasar-nya yaitu: al-Qur'an, Sunnah, Ijma', dan Qiyas. Sebagai rujukan fikihnya, menempatkan salah satu di antara 4 imam mazhab, yaitu: Imam Malik, Imam Hanafi, Imam Syafi'i dan Imam Hambali. Sementara dalam bidang teologisnya berpegang pada pemikirannya Imam alAsy'ari dan Imam al-Maturidi, dan dalam bertasawuf berpegang pada imam al-Ghazali dan Imam Junaed alBaghdadi. Kesemuanya itu disebut oleh Nahdliyin sebagai Ahlussunnah wal Jama'ah, selanjutnyamenjadi prinsip dasar dalam ideologi teologisnya. ${ }^{13}$

Demikian pula halnya dengan Alkhairaat, menjadikan Ahlussunnah wal Jama'ah sebagai faham resminya sekaligus menjadi karakter khusus bagi Abnaul Khairaat dan para ulamanya.Sebagaimanatercatat dalam

13Ja'far Shodiq, Pertemuan antara Tarekat \& NU (Studi Hubungan Tarekat dan NU dalam Konteks Komunikasi Politik 1955-2004), (Yogyakarta: Pustaka Pelajar, 2008), hlm. 70. 
karya KH. Rustam Arsjad, beberapa hal mengenai silsilah dan tradisi jaringan keilmuan Guru Tua, sekaligus menjadi dasar AD/ART Alkhairaat serta kurikulum pesantren atau madrasah Alkhairaat.

"Dalam soal akidah madhhab dan thariqah;kita berpegang dan berpedoman pada kalam atau teologi yang diajarkan oleh $\mathrm{Abu}$ alHasan al-Ash'ari dan al-Qai Abu Bakar al-Baqillani dan al-Ustadh Abu Ishaq, dan kebanyakan alJihabadah al-Bazl, yaitu aqidah yang disebutkan oleh hujjah Islam alGhazali dalam Ihya' 'Ulum al-Din. Bahkan diisyaratkan untuk dijadikan pedoman oleh Wali alQumb al-Haddad seperti ungkapan Guru Tua: "Jadikanlah Ash'ari sebagai i'tikadmu, sesungguhnya dia adalah metode (manhaj) atau jalan yang benar untuk menghindari kekufuran. Sedang dalam mazhab, saya berpegang kepada pendapat Imam al-Shafi'i dalam menetapkan hukum yang bersumber dari al-Kitab dan alSunnah, karena itulah madhhabyang termasyhur di antara madhhabmu'tabarah lainnya". ${ }^{14}$

Pertemuan antara Alkhairaat dan NU juga adapada model dan pola pendidikan yang dikembangkan oleh Alkhairaat maupun NU, yaitu pesantren. NU lahir dari pondok pesantren yang sangat lekat dengan tradisi yang menempatkan Ulama-Kiai sebagai elemen paling penting, sehingga padanya diberi penghormatan yang cukup tinggi sebagai sang "patron". Demikian pula halnya dengan Alkhairaat yang menempatkan para Habib sebagai sosok yang dihormati,

\footnotetext{
${ }^{14}$ Rustam Arsjad, Sejarah Madrasah Alkhairaat al-Islamiyah Palu, Sulawesi Tengah (Surabaya: Mulya Al-'Attasiyyah, 1956), hlm. 45.
}

karena ilmu agamanya dan karena garis keturunannya yang langsung dari Nabi Muhammad.

\section{Jaringan sosial Alkhairaat dan NU}

Jaringan sosial merupakan suatu jaringan tipe khusus, di mana ikatan yang menghubungkan satu titik ke titik lain dalam jaringan adalah hubungan sosial. Saling keterhubungan ini menurut Van Zanden merupakan interaksi sosial yang berkelanjutan (relatif cukup lama atau permanen) yang akhirnya di antara mereka terikat satu sama lain dengan atau oleh seperangkat harapan yang relatif stabil. ${ }^{15}$

Analisa jaringan dalam kajian tentang kehidupan sebuah organisasi ini ditujukan pada gambaran gejolak dari ikatan-ikatan langsung dan tak langsung di antara individu-individu yang membentuk suatu jaringan sosial. Dengan berpijak pada lokalisasi individual ke dalam jaringan-jaringan sosial, akan menjadi mungkin untuk memperkirakan sejumlah pilihanpilihan aktor dalam mengaktifkan kontak-kontak yang mengarah pada sejumlah tujuan-tujuan para aktor yang bersangkutan di dalam kehidupan sebuah organisasi. ${ }^{16}$

Bila "tindakan sosial" menjadi titik perhatiaan, akan dijumpai bahwa situasi-situasi untuk mencapai tujuantujuan tindak sosial tersebut selalu disertai dengan sejumlah formasi saling keterhubungan antaraktor yang bersangkutan dengan aktor-aktor lain.Jelas bahwa tindakan sosial yang terjadi selalu berada di dalam jaringanjaringan hubungan yang menjadi lingkungannya. ${ }^{17}$

${ }^{15}$ Rudy Agusyanto, jaringan Sosial dalam Organisasi, Ed. Rev-2 (Jakarta: Rajawali Pers, 2014), hlm. 11.

16Ibid., hlm. 55 .

${ }^{17}$ Ibid. 
Berdasarkan penjelasan di atas, maka relasi sosial yang terjalin antara Alkhairaat dengan NU, bisa dipandang sebagai sesuatu yang seolah-olah merupakan sebuah jalur atau saluran yang menghubungkan antar aktor dalam organisasi Alkhairaat dan NU, yang disebut dengan jaringan.Jaringan ini kemudian membentuk jaringan sosial-politik yang tersebar di instansiinstansi pemerintahan kota Manado, dan bahkan di instansi pemerintahan propinsi Sulut.

Jaringan-jaringan tersebut telah memberikan social capital (modal sosial) bagi Alkhairaat maupun NU yang dapat digunakan untuk memperluas jaringan yang lain, termasuk jaringan dakwah dan pendidikan.

\section{Dinamika dan Pola Relasi Alkhairaat - NU (1955-1998)}

Dalam perjalanannya, relasi yang terjadi antara Alkhairaat dan NU pasti tidak terlepas dari yang namanya dinamika, yakni perubahan-perubahan yang bisa bersifat progress (kemajuan) maupun regres (kemunduran). Hal ini karena setiap relasi yang terjadi antara individu atau kelompok, akan mendorong terbentuknya suatu gerak yang menimbulkan perubahanperubahan baik secara progresif maupun retrogresif.

Menjelaskan dinamika hubungan Alkhairaat dan NU di Manado, harus dilihat dari dua dimensi waktu.Pertama, melihat hubungan Alkhairaat - NU sebagai hubungan antara organisasi sosial keagamaan (Islam) dengan partai politik.Kedua,melihat hubungan Alkhairaat-NU di Manado pasca Khittah (NU), sebagai hubungan antara dua organisasi Islam.

Relasi Alkhairaat dan NU pada masa sebelum NU kembali ke khittah 1926-nya, merupakan relasi antara organisasi kemasyarakatan dengan partai politik.Karakteristik relasi sosial yang dikembangkan Alkhairaat saa itu lebih bersifat inklusif dan asosiasional.Inklusifdalam arti mau melibatkan diri dalam geakan dengan masuk ke ranah politik sepanjang masih dalam prinsip menegakkan syariat Islam.Dan asosiasional karena lebih mengedepankan hubungan yang bersifat impersonal dalam bingkai ideologi politik tertentu yang dianggap sesuai dengan wahyu atau firman Tuhan.

Organisasi kemasyarakatan (Ormas) merupakan kelompok orang yang secara organisatoris membentuk suatu perkumpulan secara formal yang diatur berdasarkan ketentuan organisasi tersebut untuk mencapai tujuan-tujuan yang ditetapkan dalam bidang sosial dan budaya. Perbedaan antara organisasi kemasyarakatan dengan organisasi politik (Orpol), jika organisasi politik berbentuk Partai Politik (Parpol) atau lainnya berusaha mendapatkan dan mempertahankan kekuasaan dalam struktur pemerintahan, sedangkan organisasi kemasyarakatan tidak melibatkan diri untuk ikut serta dalam peserta untuk memperoleh kekuasaan dalam pemilu. ${ }^{18}$

Yang termasuk dalam kategori organisasi kemasyarakatan, biasanya meliputi organisasi keagamaan dengan tujuan menegakkan dan memperkuat paham atau ideologi suatu mazhab tertentu, organisasi ekonomi untuk memperoleh kesejahteraan bagi kelompok anggotanya, dan organisasi sosial lainnya.Sekelompok orang berhimpun membentuk sebuah kekuatan di dalam suatu organisasi. Kendati organisasi kemasyarakatan tidak melibatkan dirinya dalam proses politik, tetapi organisasi kemasyarakatan tetap dikategorikan sebagai salah satu kekuatan politik dan

${ }^{18}$ Elly M. Setiadi dan Usman Kolip, Pengatar Sosiologi Politik, (Jakarta: Kencana, 2013), hlm. 41. 
merupakan salah satu bagian dari subsistem politik. Alasannya adalah acap kali organisasi kemasyarakatan juga memberikan input politik dalam sebuah sistem.

Hal tersebut dapat dilihat ketika organisasi-organisasi kemasyarakatan melakukan musyawarah baikmusyawarah kerja maupun musyawarah pergantian kepemimpinan dalam suatu organisasi, selain sidang komisi organisasi, juga ada sidang komisi rekomendasi yang bisasanya hasil sidang tersebut disampaikan kepada pemerintah.Hasil sidang komisi rekomendasi tersebut biasanya berisi tuntutan dan saran kepada pemerintah, tentang bagaimana seharusnya suatu pemerintahan menurut aspirasi organisasi tersebut.

Selain itu, posisi ketua umum dalam suatu organisasi kemasyarakatan selain memiliki kewenangan mengatur organisasi ia juga menduduki posisi politis yang diperhitungkan dalam realitas politik. Posisi strategi di dalam struktur politik organisasi kemasyarakatan akan menempatkan posisi tawar bagi organisasi kemasyarakatan tersebut di dalam struktur politik. Posisi tawar tersebut melahirkan konspirasi-konspirasi khusus antara partai politik dengan organisasi kemasyarakatan yang diajak bekerja sama.

Sesuatu yang diperebutkan oleh partai politik dari organisasi kemasyarakatan sudah barang tentu adalah dukungan organisasi kemasyarakatan tersebut kepada suatu partai politik yang meminangnya.Lebihlebih jika organisasi kemasyarakatan yang ada bersifat kelompok-kelompok yang didasari oleh ikatan-ikatan emosional primordial.Dalam organisasi kemasyarakatan seperti ini biasanya hubungan emosional dan primordialisme antara tokoh ketua umum dengan anggotanya sangat
kental.Misalnya Ormas keagamaan NU yang sering dipinang oleh kandidat politik untuk dijadikan sebagai simbol menarik dukungan dari anggota ormas tersebut dalam pemilihan presiden dan pilkada.

Pascakhittah, relasi sosial Alkhairaat dan NU lebih bersifat komunal, dalam arti lebih mengedepankan hubungan yang afektual, atau melibatkan hubungan timbal-balik yang akrab, dan terikat secara bersama-sama oleh kebiasaan dan kearifan lokal.Pada masa ini hubungan yang terjalin adalah hubungan antar dua organisasi Islam yang seideologi dan semazhab di Manado.

Berbagai perubahan dalam relasi sosial Alkhairaat dan NU, menunjukkan ada terjadi dinamika dalam relasi tersebut.Hal ini mendorong terbentuknya pola relasi Alkhairaat dan NU.Pola relasi ialah bentuk atau model (lebihabstrak, suatu set peraturan) yang bisa dipakai untuk membuat atau untukmenghasilkan suatu atau bagian dari sesuatu, khususnya jika sesuatuyangditimbulkan cukup mempunyai suatu yang sejenis untuk pola dasar yangdapat ditunjukkan atau terlihat, yang mana sesuatu itu dikatakanmemamerkan pola.Deteksi pola dasar disebut hubungan, bisa di maknaisebagai sebuah interaksi yang terjadi dalam masyarakat.hubunganantarindividu atau relasi sosial yangterwujud karena interaksi antaraindividu tertentu.

Dari segi karakteristik relasi sosial di atas, menunjukkan bahwa hubungan yang terjalin antara Alkhairaat dan NU di Manado, lebih dimaksudkan sebagai sebuah usaha bersama organisasi untuk mencapai tujuan bersama. Kerja sama ini timbul karena orientasi Abnaul Khairaat terhadap Alkhairaat itu sendiri sebagai 
in group-nya dan NU sebagai out-groupnya.

Secara garis besar, setidaknya terdapat tiga dimensi fundamental yang dapat dijadikan rujukan strategis, perspektif dan pendekatan dalam menggali sejauh mana organisasi Alkhairaat dan NU memiliki relasi strategis satu sama lain; yaitu pendidikan, politik, dan sosialkeagamaan.

\section{Relasi pendidikan}

Sifat agama Islam historis yang dalam perjalanannya melahirkan berbagai macam aliran baik dalam ranah fiqih, kalam, tasawuf, dan lain-lain juga mewarnai corak pendidikan Islam sepanjang sejarah. Sifat monolitik Islam pada masa awal kemunculannya berubah menjadi variatif sesuai dengan perkembangannya yang tergantung pada kondisi ruang dan waktu.Pada akhirnya pengkotakan pendidikan Islam pun mengikuti pola-pola perkembangan pemikiran.

Dalam wilayah keagamaan corak pendidikan Islam sangat dipengaruhi oleh aspek teologis dan dalam wilayah politik sangat dipengaruhi oleh aspek ideologis, sehingga dalam perjalannya hubungan antara pemikiran hukum dan pendidikan berjalan saling bergandengan.Paradigma (teologis dan ideologis) hukum mempengaruhi paradigm pendidikan, paradigm (teologis dan ideologis) pendidikan mempengaruhi paradigm hukum generasi selanjutnya, demikian seterusnya.

Ilmu agama merupakan visi pokok Alkhairaat dalam mensyiarkan syari'at Islam, melalui media pendidikan berbasis madrasah dan pesantren.Alkhairaat kemudian berkembang menghalangi masyarakat Sulut khususnya Manado, dari lajunya gerakan Zending di bidang pendidikan.Alkhairaat sebagai organisasi Islam tentunya tidak terlepas dari konsep Alqur'an dan Sunnah dalam kurikulum pendidikan agama yang diajarkannya.

Alkhairaat memang sejak semula merupakan organisasi sosial keagamaan yang memiliki tugas untuk meberikan panduan dan bimbingan, bagaimana agar perubahan kebutuhan maupun kaifiyah dalam memecahkan kebutuhan tersebut tidak mengakibatkan goncangan pada moral masyarakat dengan terus melakukan pembinaan akhlak mulia melalui pendidikan.Dengan demikian Alkhairaat di satu pihak terus melakukan perbaikan dan khidmatnya kepada umat dan bangsa, di pihak lain Alkhairaat terus berusaha agar menjaga masyarakat berpegang teguh pada sifat dan sikap yang mencerminkan akhlak mulia yang bersumber dari ajaran syari'at Islam.

Dalam kaitan koordinasi Pondok Pesantren atau Madrasah Alkhairaat takkan terlepas dari komitmen untuk mengikuti garis komando dan koordinasi Alkhairaat.Sebagai wujud komitmen pimpinan pondok pesantren melaporkan perkembangan pondok pesantren tiap akhir tahun ke PB Alkhairaat yang berpusat di Pancor.

Secara organisatoris pengurus Alkhairaat di masing-masing daerahmulai dari ranting, anak cabang dan daerah ikut berperan serta, dalam mengawasi pelaksanaan pendidikan di daerah masing-masing, serta ikut menentukan arah kebijakan pondok pesantren.Pengurus pondok pesantren atau madrasah pada umumnya merupakan pengurus Alkhairaat.Jika terjadi persoaalan-persoalan di suatu Pondok Pesantren Alkhairaat, maka pengurus-pengurus Alkhairaat ini diberikan hak wewenang untuk melakukan pengelolaan untuk meningkatkan kualitas dan kuantitas pondok pesantren tersebut, selama tidak merugikan organisasi. 
$\begin{array}{crr}\text { Kepada } & \text { kader, } & \text { organisasi } \\ \text { memberikan } & \text { kebebasan } & \text { untuk }\end{array}$ melakukan gerakan dalam melanjutkan perjuangan organisasi dengan jalan masuk ke partai politik, sejauh tidak merugikan organisasi Alkhairaat. Uniknya, kecenderungan politik kader Alkhairaat masih memegang prinsip ta'at kepada pimpinan (Guru Tua dan penerusnya), yakni sami'na wa atho'na.Prinsip inilah yang hingga kini membuat ikatan emosional itu masih ada sampai sekarang.

Kedekatan kader Alkhairaat dengan partai politik, tentunya menghadapkan mereka pada dua misi sekaligus, yakni pendidikan keagamaan dan politik kenegaraan.Kedua misi tersebut, adalah lahan yang jelas menuntut dinamisasi dan penalaran intelektual dengan segala macam sistemnya.Artinya, para kader Alkhairaat yang memiliki kepemimpinan intelektual, punya dua wajah fundamental garapan penalarannya.Kerangka pemikiran seperti inilah yang dikembangkan oleh kader yang memiliki yayasan pendidikan di bawah naungan organisasi dalam mengambil sikap politik yang kemudian diikuti oleh kader intelektual.

Hubungan kader Alkhairaat dengan partai politik ini, dimulai ketika pemilu tahun 1955.Kehadiran NU di Manado sebagai salah satu partai peserta pada pemilu 1955,ditanggapi serius hingga mendapatkan dukungan penuh dari sebagian besar Abnaul Khairaat,wa bil khusus para kader.Dukungan ini didasari atas kepenganutan terhadap mazhab dan tradisi yang sama, yakni Aswaja. Dengan demikian, menunjukkan bahwa meskipun NU secara kelembagaan pada masa itu belum terbentuk, tetapi kultur ke-NU-an umat Islam di manado diperkirakan sudah ada sejak lembaga pendidikan Islam Alkhairaat masuk di Manado pada tahun 1940-an.

Sejak awal kehadirannya di Manado hingga tahun 1950-an, pada masa itu Abnaul Khairaat mengfokuskan diri pada pengembangan pendidikan Alkhairaat dan kaderasisasi. Sehingga meskipun beberapa ulama dan tokoh Alkhairaat begitu mendukung NU pada pemilu 1955, tetapi insiatif untuk mengorganisir para ulama dan tokoh ini dalam satu wadah yaitu NU, baru muncul pada tahun 1960 yang dimotori oleh Habib Abdurrahman Mulachele seorang tokoh penting dalam pengembangan Alkhairaat di Manado.

Namun, perkembangan $\mathrm{NU}$ di Manado tidak sejalan dengan perkembangan Alkhairaat.Ketika pertumbuhan dan perluasan jaringan madrasah dan pesantren Alkhairaat semakin meningkat, aktifitas NU justru mengalami kemandekan.Padahal seharusnya dengan semakin menjamurnya madrasah dan pendidikan Alkhairaat, maka semakin banyak pula basis NU di Manado.Ini karena berbagai kebijakan Soeharto pada masa Orde Baru, membuat aktivitas NU secara nasional kedaerahan mengalami keterbatasan ruang gerak dalam mengembangkan dan membangun relasi sosial politiknya, khususnya cabang NU di wilayah Manado.

Selama masa Orde Baru ini, NU dan Alkhairaat terus bekerja dalam memelihara dan mempertahankan tradisi Aswaja.Alkhairaat berperan dalam pengembangan dan pelestarian tradisi Aswaja melalui bidang pendidikan dan dakwah.SementaraNU melalui kiprah politiknya di daerah maupun pusat, berperan mempertahankan eksistensi kaum intelektual Aswaja (termasuk ulama), serta membantu kelancaran dan keberlangungan pembangunan dan pengembangan madrasah pesantren 
(Aswaja) di Manado, secara terus menerus.

\section{Relasi politik}

Alkhairaat

dalam

mengembangkan relasi sosial dengan partai politik tertentu, bersifat inklusif.Inklusifitas dalam relasi sosial ini mulai terlihat pada pelaksanaan Pemilu Umum yang pertama di Indonesia tahun 1955, Alkhairaat secara terbuka mendukung NU yang saat itu sebagai salah satu Partai peserta dalam Pemilu tersebut. Meskipun NU saat itu tersingkir dari dua saingannya, yaitu PSII dan Masyumi yang merupakan dua Partai Islam terbesar di Manado. ${ }^{19}$

Bisa dipastikan, pada pemilu pertama tahun 1955 ini, suara terbesar NU berasal dari Basisnya yaitu Pesantren yang banyak mendominasi wilayah pulau Jawa. Sehingga mayoritas pendukungnya adalah berasal dari pulau Jawa. Herbert Feith (1999) dalam bukunya "Pemilihan Umum 1955 di Indonesia" menyebtukan bahwa dari 4 partai pengumpul suara terbanyak di Pemilu 1955: PNI, Masyumi, Partai NU, dan PKI, ada 3 partai boleh disebut sebagai "Partai Jawa" dan 1 Partai lainnya bisa disebut sebagai "Partai Luar Jawa". Dikotomi peta politik ini merujuk pada perolehan suara masingmasing keempat parpol itu dari perspektif teritori konstituennya.

Ketiga 'Partai Jawa' itu adalah PNI, Partai NU, dan PKI.Sedang 'Partai Luar Jawa' adalah Partai Masyumi, yang sebagian besar elitenya berasal dari Sumatera, Kalimantan, dan Sulawesi. Mayoritas distrik pemilihan di Sulawesi Utara khususnya Manado, Masyumi menang tipis vis a vis dari PNI.

\footnotetext{
${ }^{19}$ Sebagai pengaruh persiapan pelaksanaan Pemilu yang pertama tahun 1955, maka di Manado terdapat 2 partai Islam yang besar masing-masing Partai Masyumi dan PSII. Kedua partai Islam ini gencar menjalankan program Partai mencari anggota sebanyakbanyaknya agar menang dalam Pemilu.
}

Apresiasi Alkhairaat terhadap NU semakin terlihat ketika pada tahun 1960, Habib Abdurrahman Mulachele dan beberapa Abnaul Khairaat, bersama-sama mendirikan organisasi NU.Keberadaan NU sebagai mitra Alkhairaat di Manado saat itu dirasa perlu dalam mewadahi kader Alkhairaat yang memiliki potensi politik. Mereka itulah yang kemudian diharapkan dapat mewakili kelompok Islam tradisionalis dalam ranah politik, yang kemudian bersama-sama dengan kelompok Islam reformis, dalam mengimbangi dominasi peran politik umat Kristen di pemerintahan.

Namun di samping itu, peran mereka dalam ranah politik ini juga adalah sebagai upaya mempertahankan eksistensi kelompok tradisionalis, jika melihat semakin berkembangnya jaringan pendidikan dan paham ideologi kelompok reformis (PSII dan Muhammadiyah) atas kelompok tradisionalis (NU dan Alkhairaat) dalam kehidupan masyarakat Manado.

Sayangnya, memasuki tahun 1969 pemerintahan Soeharto mulai menerapkan kebijakan-kebijakan yang menyulitkan kiprah politik NU, sehingga menjelang pemilu 1971, aktivitas kepartaian NU hampir tidak terlihat. Kalaupun ada, itu hanya bisa terlihat dari aktivitas dakwah dan pendidikan Alkhairaat sembari mekampanyekan NU secara sembunyisembunyi.Pemerintahpun mulai melakukan berbagai tekanan kepada Pegawai Negeri Sipil (PNS) dan staf pemerintahan yang menunjukkan dukungannya kepada partai politik tertentu selain Golkar.

Tindakan pemerintah ini akhirnya berhasil memunculkan golkar sebagai pemenang mutlak pada pemilu 1971 , dengan perolehan suara $62,82 \%$ dan 236 kursi dari 360 jumlah kursi yang diperebutkan di Dewan perwakilan rakyat (DPR). Sedangkan NU 
hanya mampu memperoleh 18,68 \% dari jumlah suara dan 58 kursi. Meskipun demikian, perolehan jumlah suara NU ini setidaknya masih lebih besar dari partai-partai Islam lainnya, yaitu Parmusi dengan 5,36 \% suara dan 24 kursi, PSII 2,39\% dan 10 kursi, serta Perti dengan 0,69\% dan 2 kursi.

Kemenangan Golkar yang diikuti dengan semakin kuatnya posisi pemerintah, serta berbagai tekanan yang diarahkan kepada aktifitas sosialpolitik dan keagamaan NU,agaknya lebih menunjukkan ketakutan pihak penguasa terhadap NU sebagai organisasi politik Islam terkuat dengan pamoritas Ulama-nya,dari pada sebagai sikap partai penguasa yang oportunistik.

Sebagaimana telah dijelaskan pada bab sebelumnya, untuk lebih mengefektifkan pemerintahannya, pada tahun 1973 Soeharto melakukan penataan ulang sistem kepartaian dengan memfusikan secara paksa partai-partai Islam termasuk NUke dalam satu wadah, yaitu PPP. Bergabungnya NU ke dalam PPP inilah yang disebut oleh Laode Ida sebagai awal malapetaka bagi NU.

Perjalanan NU dalam PPP selalu diwarnai pertengkaran dengan komponen lain. Betapa tidak, meskipun NU selalu disibukkan oleh urusanurusan partai, dan ironisnya sebagai penyumbang suara terbanyak di PPP, tetapi dalam bursa ketua umum NU selalu kalah dengan komponenkomponen lain.Ternyata,massa NU hanya dijadikan penyumbang suara rutin setiap Pemilu oleh para elitenya, sehingga lembaga-lembaga dan badan otonom yang bernaung di bawah bendera NU seakan mengalami "mati suri".Keadaan inilah yang mengantarkan NU pada sebuah keputusan penting tahun 1984, yaitu kembali ke khittah 1926.
Situaasi di atas juga dialami oleh NU di Manado.Oleh karena itu, setelah NU menyatakan untuk kembali ke khittah 1926, maka setahun kemudian, tahun 1985 muncullah sosok K.H Hasyim Arsyad dan beberapa tokohpenting Alkhairaat, sebagai penginisiatif kembali terbentuknya organisasi NU di Manado.Maka pada tahun 1986, terbentuklah kembali kepengurusan NU yang baru sebagaimana telah dijelaskan pada Bab 3.

Pada masa ini, gerakan sosial Alkhairaat terlihat mengembangkan relasi bersifat komunal dengan NU.Hal ini lebih didasarkan pada hubungan kultural keduanya sebagai pewaris dan pelestari teologi dan tradisi-tradisi Aswaja.

Terbentuknya kembali NU iniketika tahun 1984 setelah menyatakan diri kembali ke khittah 1926 dan menarik diri politik praktis, barulah pihak pemerintah mengizinkan kembali dan tidak lagi mempermasalahkan maupun membatasi kegiatan-kegiatan sosialkeagamaan organisasi NU dalam masyarakat.

Hubungan Alkhairaat dan NU terus mengalami perkembangan dan terlihat semakin intensif terutama dalam melahirkan kader-kader Islam yang bisa memperkuat jaringan keduanya di pemerintahan. Terkait hal ini, ada nama Fadel Muhammad, $H$. Sunbiki, Sofyan Lahilote (mantan ketua Pengadilan Tinggi Agama Manado), Hasyim Arsyad, Hamzah Kader (Mantan Anggota DPR-D Sulut tahun 1990-an), Benny Rhamdani, dan masih banyak lagi kader NU dan Alkhairaat yang memiliki jabatan tertentu dalam pemerintahan kota Manado.

Mereka itulah yang kemudian membantu mengembangkan dan memperluas pembangunan pendidikan Islam Alkhairaat dan pesantren yang 
diasuh oleh orang-orang NU, seperti Pondok Pesantren Putri Assalam yang berdiri pada tahun 1989 dan waktu itu dipimpin oleh K.H. Abdurrahman Latukawu hingga tahun 1995 danPondok Pesantren PKP (Pondok Karya Pembangunan), berdiri pada tahun 1977 yang dipimpin oleh K.H. Rizali M. Noor.

Karena dalam relasi AlkhairaatNU sejak awal terbangun orentasi yang sama untuk mengembangkan dan memajukan umat Islam di Manado, maka kerja sama dalam perluasan jaringan politik ini terus berlangsung damai tanpa hambatan yang berarti. Namun ketika masuk era reformasi tahun 1998, mulai terjadi perubahan orentasi di tubuh NU.

Ketika pemerintahan Habibie memberikan kebebasan berpolitik yang sebelumnya di kekang oleh Soeharto, muncul ratusan partai politik yang mendaftar ke KPU untuk mengikuti Pemilu.Fenomena ini tak luput dari perhatian NU yang kemudian atas desakan warganya, akhirnya mendeklarasikan PKB sebagai wadah politik bagi warga NU.Partai ini bersifat terbuka untuk siapa saja termasuk untuk kalangan Kristen.

Kebijakan NU mendeklarasikan PKB ini, tidak mendapat dukungan dari Abnaul Khairaat di Manado.Sikap tidak mendukung ini didasarkan pada pertimbangan bahwa PKB adalah partai Nasional yang mengutamakan masyarakat mayoritas di setiap daerah. Sementara Manado jelas adalah mayoritas umat Kristen, sehingga bakal calon yangakan diusung sebagai kandidat oleh partai, besar kemungkinan berasal dari orang nonMuslim. Hal ini jelas bukan lagi menjadi orentasi awal terjalinnya relasi Alkhairaat-NU tadi.

Sekalipun secara struktural PKB bukan bagian dari NU, tetapi ia adalah bagian terpisahkan dari NU. Bagian dua sisi mata uang, seperti itulah NU dan PKB.Dapat dikatakan bahwa PKB adalah cerminan karakteristik kaum Nahdliyin. Meskipun hingga sekarang masih terjalin relasin antara Alkhairaat dan $\mathrm{NU}$, namun dalam beraafiliasi, kader Alkhairaat yang juga merupakan NU struktur, secara pribadi lebih berafiliasi kepada PPP sebagai wadah poltiknya. Dengan demikian, sebagai bentukan dukungan organisasi, maka sudah pasti suara Abnaul Khairaat lebih banyak berpartisipasi pada PPP, sebagai partai politik umat Islam.

Terlepas dari itu semua, ada beberapa hal menarik dari relasi ini.Pertama,baik Alkhairaat maupun NU di Manado dalam kondisi tertentu, terkesan menyatu secara struktural.Rais Syuriah NU Sulawesi Utara saat inimisalnya, dijabat oleh K.H. Abdul Wahab Abdul Ghafur, juga menjabat sebagai ketua Majelis Ulama Indonesia (MUI) di Sulut.Iamerupakan seorang tokoh tinggi Alkhairaat yang menjabat sebagai Penasehat Komda Alkhairaat Manado.

Pada kenyataannya, banyak peran-peran ganda sebagai pengurus Alkhairaat dan sebagai pengurus NU pada tokoh-tokoh tertentu.Hal serupa juga terjadi di Palu, hingga muncul ujaran "kalau di Sulawesi menjadi Alkhairaat, kalau sedang di Jawa menjadi NU". ${ }^{20}$

Dengan adanya peran ganda tersebut,justru menjadikan Alkhairaat dan NU di Manado semakin menonjol dalam konteks lokal,namun resikonya adalah muncul persepsi dalam masyarakat bahwa Alkhairaat itu NU. Hal ini agak berbeda halnya dengan di Palu.Adanya peran ganda tokoh-tokoh tertentu dalam Alkhairaat dan NU, resikonya adalah performa salah satu di

\footnotetext{
20Ungkapan tersebut disampaikan Helmy Arsyad pada wawancara yang dilakukan di Kantor Wilayah Kementrian Agama Sulut, 04 Maret, 2016.
} 
antara Alkhairaat dan NU menjadi tidak terlalu menonjol dalam konteks lokal.Namun tentu saja, performa Alkhairaat lebih menonjol dan kentara di Palu.Sekolah-sekolah dan madrasah,misalnya, pastilah merupakan Madrasah Alkhairaat.NU bahkantidak punya sekolah, tidak ada sekolah NU, dan karenanya NUseolah tidak eksis. ${ }^{21}$

Kedua, hal menarik dari relasi ini adalah motivasi Abnaul Khairaat dan Pengurus NU Manado dalam berpolitik, tidak bisa dilepaskan dari motivasi dakwah yang bertujuan untuk:

1. Pengembangan potensi umat Islam di berbagai bidang, khususnya politik yang selalu didominasi oleh umat Kristiani.

2. Sebagai upayamelestarikan paham keagamaan yang menurut keduanya sesuai dengan syariat Islam, yakni Ahlussunnah wal Jama'ah.

3. Sebagai langkah mempertahankan eksistensi Ulama dari kelompok pembaru,di mana mereka lebih dulu memainkan peranan penting dalam bidang keagamaan dan pendidikan dengan mendirikan masjid di beberapa desa dan mendirikan sekolahPGA (Pendidikan Guru Agama), sebagai tandingan dari HIS (Hollandzh Inlandsche School) milik Zending.

Kuatnya aktivitas dakwah ini bisa dipahami karena tindakan dan

\footnotetext{
${ }^{21}$ Kondisi ini ternyata merupakan sejenis "kesepakatan" pemuka NU dan Alkhairaat, bahwa NU akan berkiprah di Politik dan tidak boleh mendirikan madrasah. Sedangkan Alkhairaat tidak berkiprah di politik tetapi bergerak di pendidikan, sehingga boleh mendirikan madrasah. Hal ini disampaikan Abdullah As'ad Syukur (Pengurus NU Palu) dalam Akmal Salim Ruhana, "Dakwah Alkhairaat, Nahdlatul Ulama, Darud Da'wah wal Irsyad dan Muhammadiyah di Kota palau, Sulawesi Tengah", dalam M. Yusuf Asry, Gerakan dakwah Islam dalam Perspektif Kerukunan Umat Beragama (Jakarta: Badan Litbang dan Diklat Kementrian Agama RI, 2012), hlm. 326.
}

pilihan aktifis, pada dasarnya tidak bisa dilepaskan dari pengalaman pendidikan, aktivitas organisasi, dan pengalaman politik.ini semua berpengaruh pada transformasi nilai yang dilakukan aktor politik dalam proses pembuatan kebijakan publik. Adanya motivasi dakwah yang ada dalam faktor politik Alkhairaat dan NU di Manado semakin memperjelas posisi keduanya sebagai elemen gerakan sosial yang berbasis dakwah.Karena itu, menjadi maklum jika perjuangan politik yang dilakukan kedua organisasi tersebut sesungguhnya tidak bisa dilepaskan dari transformasi nilai-nilai dakwah ke publik.

Hal ini sesuai dengan salah satu hal yang dianggap bermasalah dalam tubuh umat Islam oleh Sayyid Jamaluddin adalah adanya pemikiran keliru dalam umat Islam sendiri yang memisahkan antara din dan siyasah (politik). Menurutnya sebagaimana yang dinukil oleh Syahid Muthahhari: "Dalam Islam, siyasah (politik) tidak bisa dipisahkan dari din, dan din tidak bisa dipisahkan dari politik". ${ }^{22}$

Seperti yang dikemukakan oleh Ira $M$ lapidus, di mana menurutnya sejarah Islam adalah sejarah dialog antara ranah simbol-simbol agama dengan dunia realitas sehari-hari; sejarah tentang interaksi antara nilainilai Islam dengan pengalamanpengalaman historis masyarakat Muslim yang berbeda, tetapi saling berkaitan. ${ }^{23}$

Islam memiliki sifat komprehensif karena mengatur hubungan manusia secara totalitas baik itu menyangkut hubungan manusia

\footnotetext{
${ }^{22}$ Irfan Hilmi Khomeini, Relasi Agama dan politik dalam Islam, dalam http://www.alshia.org/html/id/service/012/1 2.htm, diakses tanggal 3 Maret 2016.

${ }^{23}$ Ira M. Lapidus, Sejarah Sosial Umat Islam, Terj. Ghufron A. Mas'adi (Jakarta: PT. Raja Grafindo Persada, 1999), hlm. xii
} 
dengan sesamanya, seperti: ekonomi, sosial, politik, pendidikan, dan sanksi. Serta mengatur hubungan dengan dirinya, seperti akhlak, pakaian, makanan, dan minuman.

Karena politik dalam pandangan Islam adalah salah satu instrument atau alat perjuangan, maka dalam Islam dikenal as-siyasah asy-syar'iyyah yang menerangkan posisi politik sebagai alat dakwah.Demikian pula dalam perkembangan dakwah Alkhairaat khususnya menyangkut masalah sosial, kiprah politik sesungguhnya amat menunjang kelancaran gerakan dakwah organisasi, sebab demi kemaslahatan umat.Artinya ketika kita melihat peluang untuk memperbaiki umat dapat dilakukan melalui jalur politik, maka hal itu harus dilakukan.

\section{Relasi sosial-keagamaan}

Gerakan sosial lazim dikonsepsikan sebagai kegiatan kolektif yang dilakukan oleh sebuah organisasi tertentu untuk menciptakan kondisi sesuai dengan cita-cita organisasi tersebut. Bagi Alkhairaat, kehidupan masyarakat Manado pada saat itu, dirasakan tidak mampu menciptakan keseimbangan Islam-Kristen di berbagai bidang kehidupan. Karena itu perlu diganti dengan tatanan sosial baru yang lebih baik.

Tatanan sosial baru tersebut harus bersumber pada agama. Menurut Alkhairaat, di dalam agama terendap ekspresi tatanan suci berupa nilai dan norma yang dapat dipergunakan untuk mengganti dan melawan tatanan sekuler. Nilai dan norma yang dibuat oleh manusia dianggap banyak kelemahan dan keterbatasan, karena itu harus diganti dengan nilai dan norma ajaran agama yang lebih sempurna. Dengan demikian, gerakan sosial yang dilakukan oleh organisasi tersebut bukanlah semata-mata upaya memperdalam ajaran atau penghayatan agama, tetapi sebetulnya sebuah usaha mempengaruhi arah dan bentuk kebijakan publik supaya sesuai dengan syariat Islam.

Perkembangan Alkhairaat dalam historisnya tidak terlepas dari media dakwah yang memang sudah menjadi visi dan misi perjuangan organisasi secara khusus.Langkah dan spirit gerakan sosial Abnaul Khairaat sebagai pencerminan terhadap kiprah dan pengabdian diri dalam usaha dakwah mulai hadir di tengah-tengah masyarakat Manado sejak 1947.Kiat utama yang ditekuninya adalah membangun pencerahan keagamaan dan paradigma dalam masyarakat melalui dakwah.

K. H. Arsyad yang diutus langsung oleh Guru Tua pada tahun 1964 ke Manado, tidak akan pernah terlepas dari pergerakan sosial dakwah Alkhairaat di Manado. Dalam pandangan tokoh agama serta warga kota Manado yang menegenalnya, K.H. Hasyim Arsyad merupakan sosok yang peka terhadap nuansa sosial, tanggap serta mampu bersinergi dengan pihak manapun. Sosoknya tidak hanya dikenal di kalangan Alkhairaat saja, tetapi juga di kalangan NU Manado.

Secara asasi NU merupakan organisasi yang memiliki orientasi fundamental yang sama dengan Alkhairaat, yakni pada ranah Islamkemasyarakatan, di mana Islam merupakan suatu visi terpenting dan menjadi kepentingan mutlak bagi setiap aktivitas kedua organisasi ini. Islam tidak saja berposisi secara ideologisnormaatif akan tetapi menjadi frame of work yang melatar-belakangi setiap laju perkembangan organisasi.

Titik terpenting dalam kajian relasi ini adalah ketika NU dan Alkhairaat sama-sama berafiliasi terhadap mazhab Ahlussunnah wal Jama'ah.Aswaja dalam konteks NU yang dimotori oleh K.H. Asy'ari, secara tekstual menjadikan Alqur'an dan 
Hadits sebagai landasan utamanya, dan secara kontekstual menjadikan fikih/ushul fikih (ijma', qiyas, dan mashlahah mursalah) sebagai landasannya.Sehingga dari kedua landasan tersebut, lahir dialektika antara teks dan konteks dalam mengambil keputusan, tindakan, pemikiran, dan lain-lain. Maka tidak lain pola fikir yang dikedepankan adalah menolak bahaya (mudharat), mendatangkan kebaikan (mashlahah). Dengan mengedepankan prinsip umum "al-muhafadzotu 'alaa qadimi al-Sholikh, wal akhdzu bi al-jadiidil aslakh", yakni menjaga tradisi lama yang baik, dan mengembangkan sesuatu baru yang lebih baik. ${ }^{24}$

Prinsip itulah yang juga diterapkan oleh Guru Tua dalam keberagamaannya.Ketika menyikapi kebiasaan masyarakat Palu dalam memperingati Maulid Nabi.Guru Tua tidak pernah melarang peringatan Maulid Nabi yang sudah menjadi tradisi dalam masyarakat Palu saat itu. Tetapi dia mencegah dan menghilangkan kebiasaan makan sirih, mengisap rokok, dan makan pinang di dalam masjid, serta pembacaan buku barzanji yang terlalu panjang ketika memperingati Maulid Nabi sehingga cukup menyita waktu sedangkan kesibukan lain harus tetap berjalan. ${ }^{25}$

Dengan demikian, baik Alkhairaat maupun NU dalam aktivitas sosial-keagamaannya selalu menonjolkan sikap tasammuh (toleranasi), tawassum (moderat

${ }^{24}$ Nur Sayyid Santoso Kristeva, Sejarah Teologi Islam dan Akar Pemikiran Ahlussunah wal Jama'ah (Yogyakarta: Pustaka Pelajar, 2014), hlm. 178.

${ }^{25}$ Fatimah J. Ince Ote (Murid langsung Guru Tua yang juga pernah menjabat sebagai Ketua WIA Cabang Manado selama dua periode dari tahun 1986-1996), "Ideologi dan Kultur Alkairaat dan NU”, Wawancara, tanggal 09 Maret 2016. menghidari ekstrimitas) dan tawazzun (menyeimbangkan antara konsep habl min al-nas wa habl min Allah). Hal ini merupakan ciri-ciri utama dari prinsipprinsip interaksi sosial model komunitas Aswaja, sebagai ciri umum umat Islam Indonesia yang mayoritas menganut faham Sunni tersebut. ${ }^{26}$

Secara kelembagaan, kenyataan ini termaktub dalam Anggaran Dasar masing-masing organisasi, Alkhairaat maupun NU.Dimensi ideologis ini kemudian menjadi fundamen di dalam akselerasi sosiologis antara warga NU dan Abnaul Khairaat, terutama dalam realitas sosial masyarakat Muslim Manado dalam membangun sinergitas yang lebih dinamis.Dalam ekspresi keagamaan masyarakat Manado pada demarkasi sosiologis ini, ideologi menjadi salah satu faktor yang memperkuat jalinan keabsahan formal paradigma keislaman, yakni bermuara pada madzhab Syafi'iyah pada organisasi Alkhairaat yang juga merupakan sumber hukum yang paling banyak mewarnai aktivitas keagamaan dalam organisasi NU. Dalam hal ini, terdapat banyak sekali sebagai contoh ekspresif yang dapat dijadikan rujukan relasional, seperti tahlilan, yasinan, debaan, barzanji, mencuium tangan ustadz (guru), ziarah makam para wali, manakib, haul dan harlah.

Nahdlatul Ulama, sebagaimana dijelaskan di atas tentang kebersatuannya dalam hal 'aktor-aktor' dengan Alkhairaat, maka dakwahnya dapat dikatakan relatif sama/bersamaan. Hanya saja pamornya tampak lebih menonjol Alkhairaat dibandingkan NU. Setidaknya demikianlah jika bicara di aras lokal Palu, berkebalikan jika bicara untuk aras nasional. NU di Palu tidak memiliki sekolah atau pesantren, dakwahnya

\footnotetext{
26Umat Islam Indonesia boleh dikatakan mayoritas penganut mazhab Syafi'i.
} 
dilakukan melalui majelis-majelis taklim.Dakwah bil lisan, dengan demikian, tampak lebih menonjol dari dakwah bil qolam atau bil hal. Targeted group dakwahnya adalah masyarakat secara umum, dan substansi yang didakwahkan tentu saja ajaran Islam bercorak Ahlussunnah wal Jamaah (Aswaja) yang dalam banyak hal adalah juga apa yang didakwahkan Alkhairaat.

Dengan demikian, jelaslah bahwa secara umum, dakwah Alkhairaat dan NU di Manado dilakukan melalui dua cara. Pertama, secara kultural. Dakwah pada model ini biasanya dilakukan dengan cara memberikan pencerahan kepada umat lewat diskusi, pengajian, halaqah, seminar, pertemuan akbar, pemberdayaan umat, pembentukan institusi pendidikan untuk masyarakat, dan cara lainnya yang terkait dengan peningkatan kualitas, dan cara lainnya yang terkait dengan peningkatan kualitas, kemandirian, serta membangun budaya masyarakat.

Kedua, secara struktural.Cara dakwah dalam model ini biasanya dilakukan melalui institusi politik di mana para pemimpin umat dipercaya untuk terlibat dalam struktur pemerintahan guna membangun masyarakat politik yang beradab dan berkeadilan.

\section{Penutup}

Di atas telah dibahas tentang beberapa relasi sosial yang terbentuk antara Alkhairaat dan NU yang meliputi pendidikan, politik, dan sosial keagamaan.Berdasarkan pembahasan tersebut, dapat diketahui bahwa secara historis, relasi ini mulai terjalin sejak tahun 1955, ketika NU mengikuti pemilu umum khususnya di Manado, sampai dengan sekarang. Selama kurun waktu itu, hubungan tersebut telah terjadi pasang surut, sesuai dengan situasi dan kondisi yang melingkupinya secara alamiah, walaupun secara garis besarnya hubungan tersebut tidak mengalami gangguan yang cukup berarti kecuali ketika NU mendeklarasikan PKB dan menyebabkan Abnaul Khairaat secara pribadi lebih banyak berkiprah pada PPP untuk memperkuat jaringannya.

Oleh karena itu, dalam relasi Alkhairaat dan NU ini, tidak terlepas dari faktor-faktor yang bisa jadi mendorong terjadinya kerja sama antara Alkhairaat dan NU dan faktorfaktor yang bisa jadi sebagai penghambat dalam relasi tersebut. Ada beberapa hal yang menjadi faktor pendukung dalam relasi Alkhairaat dan NU, antara lain:

$$
\text { Pertama, dari segi }
$$

pendidikan.Sebagaimana telah disinggung bahwa Pesantren adalah lembaga pendidikan tertua di Indonesia dan tetap lestari keberadaannya, sampai dengan saat ini. Pola pendidikan ini sampai dengan sekarang, walau sudah menagalami "polesan" di sana-sini, namun secara umum masih menerapkan pola hidup sederhana serta menekankan kebersamaan dalam komunitasnya dengan tetap menempatkan sosok kiyai sebagai figur utamanya, serta masjid sebagai sentral kegiatannya.

Selanjutnya, model pendidikan yang khas ini banyak didirikan oleh orang-orang $\mathrm{NU}$ dan Alkhairaat.Para pendiri ini terkenal memiliki pengikut yang banyak dan pengaruh cukup kuat di masyakarat karena kapasitas keilmuan mereka dalam bidang agama dan sikap moderatisme dalam berosialisasi, serta akhlaknya yang mulia.

Dengan demikian, maka tidak mengherankan kalau sebagian besar pesantren di Manado, yang dirikan dan dipimpin oleh orang-orang NU dan Alkhairaat memiliki jaringan yang cukup luas dan telah mampu 
melahirkan para kader yang tidak hanya mampu berkiprah di tingkat daerah, tetapi juga di tingkat Nasional.

Kedua,dari segi politik.Ada beberapa tipologi organisasi Alkhairaat dalam memilih partai politik, yaitu: memiliki strategi yang sama dalam hal memanfaatkan peluang, menebarkan ideologi, membangun tindkaan kolektif, dan membentuk jaringan gerakan menegakkan syariat Islam.Tipologi inilah yang terlihat pada NU, sehingga terbentuknya relasi antara Alkhairaat dan NU sejak tahun 1955, didukung oleh adanya kesamaan dalam hal memanfaatkan peluang dan membentuk jaringan gerakan.Dalam membentuk dan mengembangkan jaringan yang lebih luas dalam berdakwah, maka kiprah politik menjadi pedukung dalam memanfaatkan peluang untuk menunjang kelancaran dakwah organisasi.

Adapun jika terjadi perbedaaan sekaligus persamaan dalam mengembangkan strategi menegakkan syariat Islam, ini karena di lapangan kerapkali berhadapan dengan kemauan pemerintah, respons kekuatan politik dan kelompok kepentingan yang kurang lebih sama.

Ketiga, dari segi sosialkeagamaan.Sebagaimana telah dijelaskan, Alkhairaat baik secara kelembagaan maupun aktivitas Abnaul Khairaat dalam peribadatan dan interaksi sosial kebangsaan, telah merepresentasikan dirinya sebagai pengawal tradisi Aswaja.Sementara NU dan Aswaja mempunyai hubungan yang tidak dapat dipisahkan, NU sebagai organisasi/jam'iyyah merupakan alat untuk menegakkan Aswaja, dan Aswaja merupakan akidah pokok Nahdlatul 'Ulama.

Dalam cakupan wilayah Indonesia Timur, Alkhairaat memiliki pengaruh yang lebih dari pada NU.Tetapi pengaruh NU dalam tingkat nasional bahkan internasional tidak bisa dianggap kecil.NU memiliki pengaruh yang cukup kuat dalam dalam pemerintahan Indonesia, bahkan bisa dibilang menjadi bagian yang integral dalam dinamika bangsa Indonesia.

Adanya posisi tawar tersebut, mendorong Alkhairaat dan sebagai mitra memiliki hubungan saling pengaruh yang cukup kuat dalam menjaga benteng faham moderat komunitas Aswaja, sebagai warisan dan kiblat Islam yang sangat bernilai di wilayah Indonesia Timur.Posisi tawar ini pula yang menjadi nilai tukar yang menguntungkan dalam relasi Alkhairaat-NU sehingga keduanya mampu membentuk, mengembangkan dan mempertahankan jaringan sosialnya baik di tingkat daerah, maupun pusat.Melalui jaringan sosial yang kuat dan luas inilah, Alkhairaat dan NU kemudian mampu membawa perubahan dalam perkembangan masyarakat Muslim di Manado, baik dalam bidang pendidikan, politik, dan sosial keagamaan.

Dengan demikian, adanya kesamaan ideologi dan kultur keagamaan yang berafiliasi pada paham Ahlussunnah wal Jama'ah, menjadi faktor pendukung yang paling utama dalam relasi Alkhairaat dan NU.Selain itu, persamaan orentasi di satu sisi dan kondisi masyarakat kota Manado di sisi yang lain, juga menjadi suatu keniscayaan dalam relasi Alkhairaat dan NU.

Relasi sosial dalam masyarakat tidak selamanya berjalan baik, demikian pula dengan relasi Alkhairaat dan NU di Manado, terkadang ada faktor yang menghambatnya.Adapun faktor penghambatdalam relasi sosial Alkhairaat-NU adalah ketika berbagai dinamika politik yang sering terjadi di tubuh NU, secara tidak langsung akan menimbulkan pergeseran sosiologis kaum nahdliyin. 
Maka NU yang sebelumnya cenderung diurus oleh kalangan tradisional yang lebih mendasarkan pada pola-pola hubungan emosional, ke depan ia akan menjadi organisasi modern yang dikelola oleh kalangan profesional yang lebih mendasarkan pada pola-pola hubungan rasional. Hal ini jelas akan sangat bertentangan dengan realitas kehidupan sosial abna'Alkhairaat secara keseluruhan yang pada umumnya baik di pusat maupun daerah khususnya Manado, sangat mengutamakan hubungan emosional ketimbang rasional.

Terlepas dari hambatan tersebut di atas,bertemunya kedua kepentingan organisasi Alkhairaat dan NU telah menjadi dasar terjalinnya relasi Alkhairaat dan NU sehingga tercipta suatu hubungan yang saling menguntungkan antara Alkhairaat dan NU selama tahun 1955 sampai dengan 1998. Sebagai hasil dari relasi sosial (pendidikan, politik dan sosialkeagamaan) tersebut, adalah terakomodirnya apa yang menjadi kepentingan NU oleh Alkhairaat demikian juga terakomodirnya kepentingan Alkhairaat oleh NU.

\section{Daftar Pustaka}

Azra Azyumardi, Jaringan Global dan Lokal Islam Nusantara, Bandung: Mizan, 2002.

Arsjad Rustam, Sejarah Madrasah Alkhairaat al-Islamiyah Palu, Sulawesi Tengah, Surabaya: Mulya Al-'Attasiyyah, 1956.

Agusyanto Rudy, jaringan Sosial dalam Organisasi, Jakarta: Rajawali Pers, 2014.

Fathoni Khoirul \& Zen Muhammad, $N U$ Pasca Khittah (Prospek Ukhuwah dengan Muhammadiyah, Yogyakarta: Media Widya Mandala, 1992.

Jumat Gani, Nasionalisme Ulama: Pemikiran Politik Kebangsaan Sayyid Idrus Bin Salim Aljufry, 1891-1969 Jakarta: Kementrian Agama RI, 2012.

Kartodirjo Sartono, Pemberontakan Petani Banten 1888 Jakarta: Pustaka Jaya, 1984.

Karim A. Gaffar, Metamorfosis $N U$ dan Politisasi Islam Indonesia, Yogyakarta: Pustaka Pelajar \& LKiS Yogyakarta, 1995.

Khomeini Irfan Hilmi, Relasi Agama dan politik dalam Islam, dalam http://www.alshia.org/html/id/se rvice/012/12.htm, diakses tanggal 3 Maret 2016.

Kompasiana, "Struktur Sosial dan Interaksi Sosial", dalam http://www.kompasiana.com/, akses tanggal 26 Mei 2016.

Lapidus Ira M, Sejarah Sosial Umat Islam, Terj. Ghufron A. Mas'adi Jakarta: PT. Raja Grafindo Persada, 1999.

Muhtadi Asep Saeful, Komunikasi Politik Nahdlatul Ulama: Pergulatan Pemikiran Politik Radikal dan Akomodatif, Jakarta: LP3ES, 2004.

Sulaiman P.L M. Noor., Al-Khairaat dan Perubahan Sosial Masyarakat Sulawesi Tengah, Palu: LP3M STAIN Dato Karama, 2000.

Shodiq Ja'far, Pertemuan antara Tarekat \& NU (Studi Hubungan Tarekat dan NU dalam Konteks Komunikasi 
Politik 1955-2004), Yogyakarta: Pustaka Pelajar, 2008.

Setiadi Elly M. dan Kolip Usman, Pengatar Sosiologi Politik, Jakarta: Kencana, 2013.

Salim Ruhana Akmal, "Dakwah Alkhairaat, Nahdlatul Ulama, Darud Da'wah wal Irsyad dan Muhammadiyah di Kota palau, Sulawesi Tengah", dalam M. Yusuf Asry, Gerakan dakwah Islam dalam Perspektif Kerukunan Umat Beragama, Jakarta: Badan Litbang dan Diklat Kementrian Agama RI, 2012.

Santoso Kristeva Nur Sayyid, Sejarah Teologi Islam dan Akar Pemikiran Ahlussunah wal Jama'ah, Yogyakarta: Pustaka Pelajar, 2014.

Zada Khamami \& Sjadzili A. Fawaid (ed.), Nahdlatul Ulama: Dinamika Ideologi dan Politik Kenegaraan, Jakarta: Kompas, 2010.

Fatimah J. Ince Ote (Murid langsung Guru Tua yang juga pernah menjabat sebagai Ketua WIA Cabang Manado selama dua periode dari tahun 1986-1996), "Ideologi dan Kultur Alkairaat dan NU", Wawancara, tanggal 09 Maret 2016. 